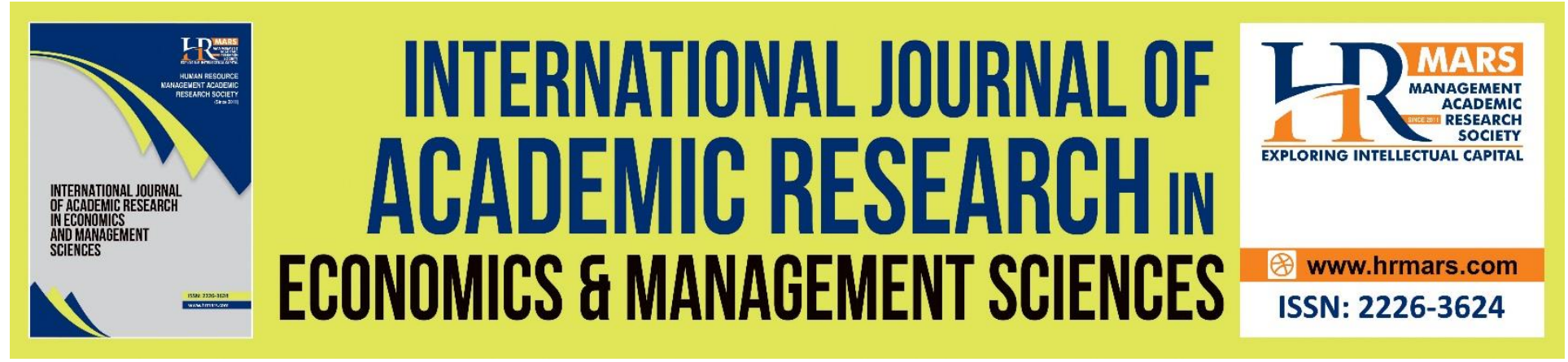

\title{
Competitor Accounting and Profitability of Listed Financial Institutions in Nigeria
}

Celestine Anayo Egbuhuzor, Douye Akoba, Gospel J. Chukwu

To Link this Article: http://dx.doi.org/10.6007/IJAREMS/v10-i3/11084 DOI:10.6007/IJAREMS/v10-i3/11084

Received: 10 July 2021, Revised: 12 October 2021, Accepted: 28 October 2021

Published Online: 06 September 2021

In-Text Citation: (Egbuhuzor et al., 2021)

To Cite this Article: Egbuhuzor, C. A., Akoba, D., \& Chukwu, G. J. (2021). Competitor Accounting and Profitability of Listed Financial Institutions in Nigeria. International Journal of Academic Research in Economics and Management and Sciences, 10(3), 301-313.

Copyright: ( 2021 The Author(s)

Published by Human Resource Management Academic Research Society (www.hrmars.com)

This article is published under the Creative Commons Attribution (CC BY 4.0) license. Anyone may reproduce, distribute, translate and create derivative works of this article (for both commercial and non-commercial purposes), subject to full attribution to the original publication and authors. The full terms of this license may be seen

at: http://creativecommons.org/licences/by/4.0/legalcode

\section{Vol. 10, No. 3, 2021, Pg. 301 - 313}

Full Terms \& Conditions of access and use can be found at http://hrmars.com/index.php/pages/detail/publication-ethics 


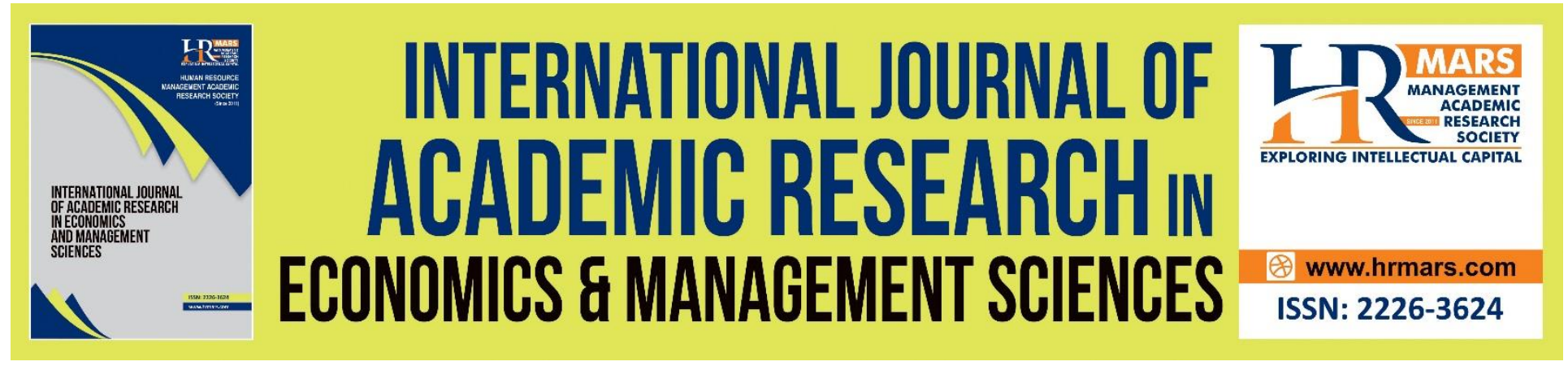

\title{
Competitor Accounting and Profitability of Listed Financial Institutions in Nigeria
}

\author{
Celestine Anayo Egbuhuzor \\ Ignatius Ajuru University of Education, Rumuolumeni, Port Harcourt, Nigeria

\begin{abstract}
Douye Akoba
Department of Accounting, Ignatius Ajuru University of Education, Rumuolumeni, Port Harcourt, Nigeria
\end{abstract} \\ Gospel J. Chukwu \\ Department of Accountancy, Ken Saro Wiwa Polytechnic, Bori, Rivers State, Nigeria \\ Email: gospeljchukwu@gmail.com
}

\begin{abstract}
Companies strive to be profitable to maximize shareholder's wealth. They can only do that by mastering their current trend in the business environment and having competitive strategies that will give them an edge over other companies. This study examined the relationship between competitor accounting and profitability of listed financial institutions in Nigeria. Specifically, the study investigated the relationship between competitor cost assessment, competitive position monitoring, competitor's financial statement performance appraisal, and net profit margin of listed financial institutions in Nigeria. The ex-post facto research design was used. The study population was fifty-three (53) out of which a sample size of forty (40) was obtained using judgmental sampling technique. Multiple regression was used to test the postulated null hypotheses with the aid of Stata12. The study revealed a positive and significant relationship between competitor cost assessment and net profit margin, a negative and significant relationship between competitive position monitoring and net profit margin, and a positive and insignificant relationship between competitor financial statement performance appraisal and net profit margin. The implication of these findings is that managers of listed financial institutions in Nigeria should continuously analyse the financial statement of competitors to gain competitive advantage and be profitable.

Keywords: Competitor Accounting, Competition, Competitiveness, Profitability, Competitor Position Monitoring
\end{abstract}




\section{Introduction}

Decades ago, and presently, businesses around the world have strived to achieve set out goals using available resources at their disposal. The business environment in which the business finds itself is characterized by factors such as advances in the market, constant changes in customer preference, and intense competition. Companies are assessed and rate with a lot of indices of which profitability is one. Profitability is one of the measures of organizational performance. The extent of a company's profitability is determined by its competitive advantage and strength over other competing firms. In Nigeria, companies strive to be profitable to maximize shareholder's wealth. They can only do that by mastering their current trend in the business environment and having competitive strategies that will give them an edge over other companies. Profitability refers to the operating efficiency of a firm, that is the ability to raise profit from sales of assets and certain capital stock (Husnan, 2001; Shapiro, 1991).

As the business world gets more competitive, companies tend to seek out more information and spend more time and effort analysing them for the improved competitive advantage which will have a multiplier effect on the profitability of the firm in general. This has awoken the urgent need for competitor accounting for success in todays and tomorrow's competitive environment. Competitor accounting, also refers to as competitor analyses is described as "Know your enemy accounting" (Akenbor \& Okoye, 2011). This is a term used by Ward (1992) to refer to the calculation of the relative production costs of competitors. It also explores the likely strategies of competitors and the evaluation of their potential effects on the profits of the firm.

Financial institutions in Nigeria's business environment also compete to gain a market share. In Nigeria, there are opportunities for new entrants looking to operate in the banking and insurance sector, as 4 out of 10 Nigerians are still underbanked in that they lack the access to a full range of basic financial services. Coupling this lack of banking access with a growing middle class that is seeking an improved banking experience and businesses searching for lower and competitive interest rates, companies looking for opportunities in the financial service industries in Nigeria certainly have an advantage. This has significantly aroused the competitiveness of the financial service industries.

\section{Statement of Problem}

Recently, the frequent inactivity and eventually collapse of financial institutions in Nigeria as a result of a lack of profitability from its activity and inability to incorporate competitor accounting in their firms have motivated this study. This is evident as Nigeria Deposit Insurance Corporation (NDIC) since its incorporation in 1998 till date has carried out liquidation activities on 425 financial institutions in the country.

Most financial institutions lack adequate knowledge and information about their industry and competitors. Most that do gather information about competitors, see it as costly. Also, most company's strategic plans are defensive instead of offensive and responsive. A good example is Nokia's inability to adopt the new trend in innovation which is Android. Before it could realize it, it has lost its market share to other competitive brands like Samsung etc.

Across the shores of Nigeria, Sliman and Mohammad (2015); Armstrong et al (1998), and Alsoboa and Alalaya (2015) all research on competitor accounting and profitability in manufacturing and construction companies and used primary data through the use of a structured questionnaires. This method does not seem appropriate to the researcher as competitor cost cannot be 
appropriately revealed through a structured questionnaire. In Nigeria, Akenbor and Okoye (2011) and Chiekezie et al (2014) did their research on competitor accounting and financial performance of listed manufacturing companies in Nigeria. These works though carried out in Nigeria and used secondary data from the Nigeria stock exchange and CBN statistical bulletin, were only carried out in the manufacturing sector of the economy, as non was carried out in the financial institutions in Nigeria. Therefore, to fill the gap thus identified, this study empirically examined the relationship between competitor accounting and profitability of listed financial institutions in Nigeria.

The following research hypotheses were formulated for the study.

$\mathrm{Ho}_{1}$ : There is no significant relationship between competitor cost assessment and net profit margin of listed financial institutions in Nigeria.

$\mathrm{Ho}_{2}$ There is no significant relationship between competitive position monitoring and net profit margin of listed financial institutions in Nigeria.

$\mathrm{Ho}_{3}$ There is no significant relationship between competitors financial statement performance appraisal and net profit margin of listed financial institutions in Nigeria.

\section{Literature Review}

\section{Concept of Competitor Accounting}

The concept of competitor accounting arises from the need for companies to study other companies in the same industry and come up with strategic plans to gain a competitive advantage. It allows the company to perform its value-adding activities more effectively and/or efficiently than its rivals. The competitiveness of an organization is defined as the potential to achieve a higher performance based on a creative approach to human, capital, and natural resources (Vladimirov et al., 2012).

Akenbor and Okoye (2011) viewed competitor accounting as "Know your enemy accounting". This concept as defined by Ward (1992) refers to the calculation of the relative production costs of competitors. It also explores the likely strategies of competitors and the evaluation of their potential effects on the profits of the firm. Competitor accounting comprises the analysis of information from accounting relating to competitors. It is thereby supposed to gain detailed insight into their present cost and finance situation, to determine one's competitive position, and to predict the future strategic behaviour of the competitors (Heinen \& Hoffjan, 2005). In a nutshell, competitor accounting involves collecting information about competitors and using that information to predict (i) how the competitor is likely to react to our strategic decisions and (ii) what the competitor's future strategies will be and how we might react to them to minimize any adverse effects on our company.

Competitor accounting is an essential component of corporate strategy. A typical situation in Nigeria business environment is the competition in the Telecommunication industry between MTN Nigeria and GLO mobile. This competition has been healthy, thereby improving the quality of services rendered to the customers since they both compete for the same market share. This same competition has moved to other sectors like the financial sector of which this study is centered. Recently banks and other financial institutions have introduced services and technologies that distinct their institution from others which will in return give them a competitive advantage over others in the industry. An example of such innovation is the 
introduction of mobile banking and easy banking through the aid of mobile gadgets. Guaranty trust bank started with $* 737 \#$ of which today most financial institutions have keyed into it for better competitive advantage and service delivery.

In this study, the various dimensions of competitor accounting are competitor cost assessment, competitive position monitoring, and competitor's financial statement performance appraisal.

\section{Concept of Profitability}

Profitability means the ability to make a profit from all the business activities of an organization, company, firm, or enterprise. It shows how efficiently the management can make a profit by using all the resources available in the market. According to Enekwe et al (2013), profitability is the ability of an enterprise to get sufficient returns on the capital and employees used in the business operation. Husnan (2001) sees profitability as the ability of the firm to raise profit from sales, assets, and certain capital stock. Profitability is a significant factor that notifies how well or bad an organization is performing (Egbuhuzor, 2016). Profit is the ultimate output of a company, and it will have no future if it fails to make sufficient profit. Therefore, financial managers should continuously evaluate the efficiency of their company in terms of profits.

Profitability is one of the most frequently used financial performance indicators in an organization. Profitability ratio in one form or another, are intended to measure how efficiently the firm manages its operations. Profitability in studies involving financial institutions is often measured using return on assets and return on equity (Chukwu \& Egbunike, 2015; Chukwu \& Salifu, 2018), even in cases which examined the competition and profitability of banks (Tan \& Floros, 2012; Yuanita, 2019). The profitability ratios to be used in this study are Net Profit Margin (NPM) and Return on Assets (ROA).

\section{Theoretical Framework}

The following theories provide the framework for this study:

\section{Agency Theory}

The proponents of this theory are Jensen and Meckling in 1976. Agency theory is developed as a framework for analysing conflicting interests between key stakeholders, in addition to the development of mechanisms for resolving conflicts (Tipuric, 2008). The Agency theory objective is to determine an optimal contract between principal and agent. The relationship between principal and agent based on the contract is a focal point of agency theory. The theory postulates the behavioural attributes of the economic man to transactional characteristics as a devious; selfinterest seeking being with divergent, opportunistic, and sub-optional pursuit different from efficiency goal of the firm. The theory further presumes that maximization of firm value would be feasible under managerial discretional disposition (Twonbull, 1997). Therefore, to boost the profitability and maximize firms value managers should incorporate effective strategic plans that will enable the company to gain a competitive advantage over others in the industry without bringing into play the agency problem.

This theory presumes that maximization of firm value would be feasible under managerial discretional disposition (Twonbull, 1997). Therefore, to boost the profitability and maximize firms value managers should incorporate effective strategic plans that will enable the company 
to gain a competitive advantage over others in the industry without bringing into play the agency problem.

\section{Rogers's Theory of Diffusion and Perceived Attributes}

The proponent of this theory is Everett Rogers in 1962 in his book tilled diffusion of innovation. Rogers opined that diffusion is the process by which an innovation is communicated over time among the participants in a social system. It is agreed that the adoption of competitor accounting is influenced by the firm's perception of the usefulness of the innovation, such that those who perceive it as being highly useful would adopt it fully while those who view it as less useful would either not adopt it or partially adopt it. Therefore, this theory is relevant to this study as it will enlighten managers and owners of the company of the need to employ innovation in Information, Technology, and communication (ITC) as it is a driving force to gain a competitive advantage in today's competitive business environment.

\section{Empirical Review}

Empirical findings in respect to the topic of discussed has been expressed by various research. Feng et al. (2013) carried out research on the impact of competitive intensity on the profitability of investments and future stock returns. The sample of the study was based on the intersection of firm-years available on the EDGAR filings database, where textual data on perceived competition, from annual file for years 1995-2006. A descriptive statistic was also employed. The study revealed that the rate of diminishing returns on investment is negatively related to the frequency of references to competition in the 10-K.

Alsoboa and Alalaya (2015) carried out a study on the practices of competitor accounting and its influence on the competitive advantage in Jordanian manufacturing companies. A survey on Jordanian manufacturing companies was conducted for data collection. Descriptive statistics, One-sample t-test and multiple regression analysis were used in data analysis. The results of multiple regressions showed that these techniques contribute significantly and explain a high percentage of variation in the competitive advantages of Jordanian manufacturing companies. Shecderbek (2010) carried out a comparative study on the effect of competitor costs assessment on the performance of manufacturing and service industries in Sri Lanka. A total of 113 selected manufacturing and service firms were selected for the study. The study revealed that competitor cost assessment has a strong impact on service firms in Sri Lanka.

Also, Usman and Bello (2019), carried out a study on the application of competitor focused accounting (CFA) method as competitive advantages in foods and baking enterprises in Kano, Jigawa, and Bauchi states of Nigeria. All foods and baking enterprises in the three states were used as the population of the study. While nine (9) enterprises three (3) from each state were used as the sample of the study. Ninety (90) questionnaires were administered out of which seventy-eight (78) were collected. The one-sample t-test and the frequency table were used to analyse the data gathered. The findings of the study reveal that all aspect of competitor focused accounting method captured in the study (Competitor Cost Assessment, Competitor Position Monitoring, Competitor Appraisal based on Financial Statement) were significantly used in the foods and baking enterprises in the three (3) states.

A study by Piatkowski (2012) on factors strengthening the competitive position of SME sector enterprises examined and identify the factors having a direct impact on creating the 
competitive position and the development of enterprises as well as mutual relations between entrepreneurs and their business partners. Descriptive-survey research design was used in the study with a random sample of 520 micros, small and medium enterprises. 460 entities were selected from this group, which answered all questions included in the questionnaire. The study revealed that the main factors having a direct impact on creating the competitive position and development of companies remain the quality of offered products (services) and an accordingly conducted price policy.

In an attempt to ascertain the relevance of competitor accounting, Phornlaphatrachakorn (2019) carried out a study on competitor accounting and marketing performance: an empirical investigation of electronics and electrical appliance businesses in Thailand. The study made use of 175 electronics and electrical appliance businesses in Thailand as its sample size alongside a structured questionnaire. Correlation analysis and multiple regression analysis were used in testing the research hypotheses. The study revealed that both competitor cost assessment and competitor performance appraisal have significant effects on marketing capability and competitive advantage while competitive position monitoring has an important influence on marketing capability, marketing effectiveness, and marketing performance.

Akenbor and Okoye (2011) carried out a study competitors accounting and corporate profitability of manufacturing firms in Nigeria. The population of the study comprised of quoted manufacturing companies in the Nigerian Stock Exchange fact book of 2009. Secondary data were collected from companies Annual Reports of various years and the Central Bank of Nigeria (CBN) Statistical Bulletin for fifteen years (i.e. 1994-2008). Multiple Regression Analysis was used to analyse the data gathered. The study revealed that Competitor Accounting has a positive significant impact on the profitability of a manufacturing firm.

Several reforms were implemented in China to stabilise the banking sector and enhance competitiveness in the industry. This background motivated Tan (2016) who investigated how competition as well as risk-taking affects the profitability of firms in China's banking industry. The study also examined the joint effect of the two variables on profitability. Data was obtained from 41 Chinese banks over the period 2003 to 2011, and analysed using Generalized Method of Moments. Results showed that competition did not significantly affect profitability

\section{Methodology}

The ex post facto research design was adopted for this study with a population of fifty-three (53) listed financial service firms as listed in the Nigeria stock exchange in 2019. However, after a careful examination, only forty-four (44) financial institutions were selected as the accessible population while Nine (9) financial institutions were not selected for lack of adequate data for the period under study 2009-2018. A sample size of forty (40) listed financial institutions was selected using simple random sampling procedure. The descriptive statistics and multiple regression were used to test the postulated null hypotheses with the aid of STATA12 statistical software.

\section{Model I (Panel Regression Model)}

$P=\quad f(C C A+C P M+C F S P A+i t)$.

$\mathrm{NPM}=\quad \mathrm{f}(\mathrm{CCA}+\mathrm{CPM}+\mathrm{CFSPA}+\mu)$

Therefore, the model is 


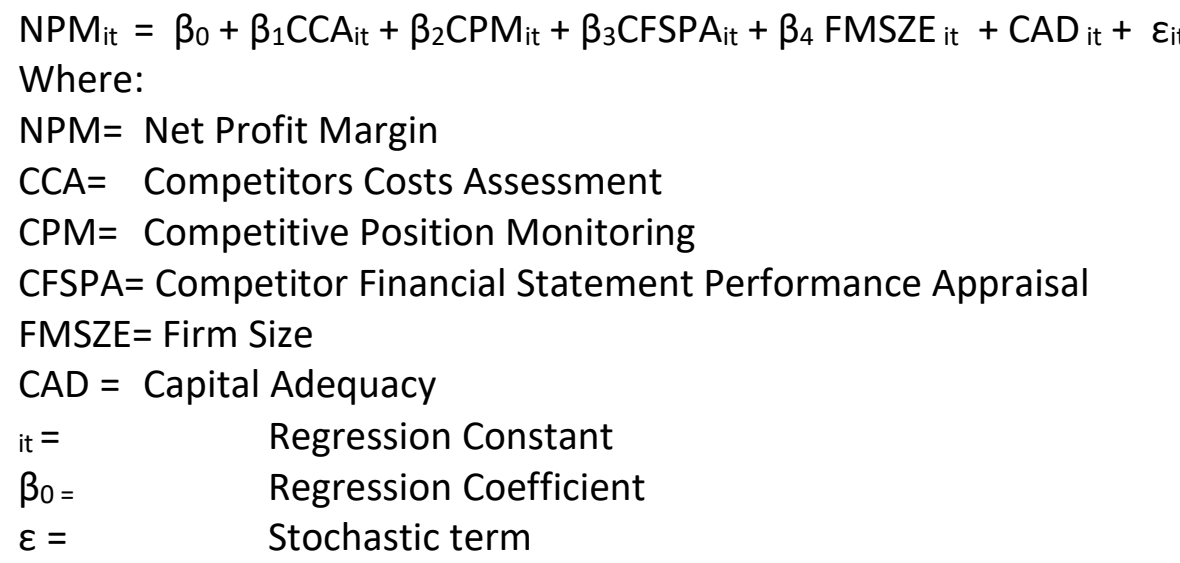

\section{Operationalization and Measurement of Variables}

Net Profit Margin (NPM): In this study, net profit margin is proxied by the percentage of profit a company produces from its total revenue.

$$
\text { Net Profit margin }=\frac{\text { Profit After Tax }}{\text { Total Revenue }} * 100
$$

Competitors Costs Assessment (CCA): This was measured in terms of the operational efficiency of the firm, which is the ratio of gross earnings to total assets as obtained from the financial statement of listed financial institutions.

Mathematically it is CCA $=\frac{\text { Gross Earnings }}{\text { Total Asset }}$

Competitive Position Monitoring (CPM): This was operationalized in terms of the market share of the firm, which is the ratio of a firm's earnings to the industrial earnings of the respective years.

Mathematically it is CPM $=\frac{\text { Firms Earnings }}{\text { Industrial Earnings }}$

Competitor Financial Statement Performance Appraisal (CFSPA): This was measured in terms of the firm's liquidity, which is the ratio of current assets to current liabilities.

Mathematically it is CFSPA $=\frac{\text { Current Assets }}{\text { Current Liabilities }}$

Firm Size (FMSZE): In this study, the firm size is seen as the total asset of the company. This is the total value of the asset as stated in the financial statement i.e. Total non-current asset + Total current Asset. This value of total assets was returned to the natural logarithm of a number (LN) in excel for the study.

Capital Adequacy (CAd): This is a control variable used in the model for the study. It was measured as;

$$
\mathrm{CAd}=\frac{\text { Total Equity }}{\text { Total Assets }}
$$

Chukwu and Egbunike (2017) used capital adequacy as a control variable In a study involving CEOs quality of human capital and performance of banks in Nigeria. 
INTERNATIONAL JOURNAL OF ACADEMIC RESEARCH ECONOMICS AND MANAGEMENT SCIENCES

Vol. 10 , No. 3, 2020, E-ISSN: 2226-3624 ㄷ 2020 HRMARS

\section{Test of Hypothesis and Findings}

Multiple regression results with NPM as dependent variable

$N P M_{i t}=\beta_{0}+\beta_{1} C C A_{i t}+\beta_{2} C P M_{i t}+\beta_{3} C_{F S P A}+\beta_{4}$ FMSZE $_{i t}+C A D_{i t}+\varepsilon_{i t}$

Linear regression

$\begin{array}{llr}\text { Number of obs } & = & 373 \\ \mathrm{~F}(5,367) & = & 4.15 \\ \text { Prob }>\mathrm{F} & = & 0.0011 \\ \text { R-squared } & =0.1112 \\ \text { Root MSE } & =93.401\end{array}$

\begin{tabular}{|c|c|c|c|c|c|c|}
\hline \multirow[b]{2}{*}{ npm } & \multicolumn{3}{|c|}{ Robust } & \multirow[b]{2}{*}{$P>|t|$} & \multirow[b]{2}{*}{ [95\% Conf. } & \multirow[b]{2}{*}{ Interval] } \\
\hline & Coef. & Std. Err. & t & & & \\
\hline $\mathrm{CCa}$ & 1.013319 & .3521893 & 2.88 & 0.004 & .3207565 & 1.705881 \\
\hline cpm & -1.412899 & .4342736 & -3.25 & 0.001 & -2.266876 & -.5589218 \\
\hline cfspa & .6437903 & .3843799 & 1.67 & 0.095 & -.1120732 & 1.399654 \\
\hline fmsze & 19.07974 & 5.417397 & 3.52 & 0.000 & 8.426703 & 29.73277 \\
\hline cad & 33.81742 & 11.9816 & 2.82 & 0.005 & 10.2562 & 57.37863 \\
\hline _cons & -384.8799 & 111.9287 & -3.44 & 0.001 & -604.982 & -164.7778 \\
\hline
\end{tabular}

Source: Output from STATA version 12

The above table presents the model which regress net profit margin (npm) against competitor cost assessment (cca), competitive position monitoring (cpm) and competitor financial statement performance appraisal (cfspa) alongside the moderator variables firm size (fmsze) and capital adequacy (cad). The standard robust error in the regression addresses heteroskedasticity. The $F$ statistics in Table 8 show that the model exhibit excellent fit at Prob $>F=0.0011$ and that the independent variables statistically and significantly predict the dependent variable. The independent variables in the model explain $11 \%$ of the variation in net profit margin.

\section{Test of Hypotheses}

Ho $_{1}$ : There is no significant relationship between competitor cost assessment and net profit margin of listed financial institutions in Nigeria.

It shows a positive and significant relationship between competitor cost assessment and net profit margin ( $p$-value $=0.004)$. It means that a $1 \%$ increase in competitor cost assessment will bring about a $1.01 \%$ increase in net profit margin all other variables are held constant. From the result, we reject the null hypothesis and therefore concluded that "There is significant relationship between competitor cost assessment and net profit margin of listed financial institutions in Nigeria."

$\mathrm{Ho}_{2}$ There is no significant relationship between competitive position monitoring and net profit margin of listed financial institutions in Nigeria. 
The regression result revealed a negative and significant relationship between competitive position monitoring and net profit margin $(p$-value $=0.001)$. This means that all other variables held constant, a $1 \%$ increase in competitive position monitoring leads to a $141.3 \%$ decrease in net profit margin of listed financial institutions in Nigeria. From the result, we reject the null hypothesis and therefore concluded that "there is a significant relationship between competitive position monitoring and net profit margin of listed financial institutions in Nigeria."

Ho3 There is no significant relationship between competitor financial statement performance appraisal and net profit margin of listed financial institutions in Nigeria.

The regression result revealed a positive and insignificant relationship between competitor financial statement performance appraisal and net profit margin ( $p$-value $=0.095)$. This means that all other variables held constant, $1 \%$ increase in competitor financial statement performance appraisal will lead to a $64 \%$ increase in net profit margin of listed financial institutions in Nigeria. From the result, we accept the null hypothesis that states that "There is no significant relationship between competitor financial statement performance appraisal and net profit margin of listed financial institutions in Nigeria."

\section{Discussion of Findings}

The study revealed a positive and significant relationship between competitor cost assessment and net profit margin of listed financial institutions in Nigeria. This led to the rejection of $\mathbf{H o}_{1}$. This finding may be a result of the fact that competitor cost assessment being carried by most financial institutions are detailed to ascertain cost leadership in the industry. A comprehensive assessment by a firm in an industry of cost leadership will help to implement policies that will enhance profitability. This is in line with the assertion of Hesford (2008) that the increased use of accounting information has a positive influence on the effectiveness of competitive intelligence and increased effectiveness of competitive intelligence has a positive effect on corporate performance. Also, Johnson (2002) concluded that information gained from the annual financial statement could influence strategic decisions taken by competitors thereby leading to competitive advantage. This finding is in disagreement with the work of Heinen and Hoffjan (2005) that revealed that cost leaders who are aware of their cost lead, act differently than cost leaders without such knowledge. This goes to say that informed cost leaders implement their strategic decision much more resolutely. It is also true that firms which are aware of their competitive strengths at the cost level, employ this knowledge by selecting cost leadership as their fundamental strategic orientation. This finding implies that strategies of financial institutions who have not informed cost leaders in the industry will hamper their profitability. Also, the study revealed a negative and significant relationship between competitive position monitoring and net profit margin of listed financial institutions in Nigeria. this led to the rejection of $\mathrm{Ho}_{2}$. This finding may be a result of the fact that every firm strives to be more profitable than its competitor within an industry, therefore need to carry out a survey of its position and that of its competitors in an industry. This study is in line with the finding of Akenbor and Okoye (2011) that revealed that competitor accounting has a positive significant impact on the profitability of manufacturing firms. This finding is supported by the agency theory as managers of financial 
institutions should incorporate effective strategic plans that will enable companies gain competitive advantage in the industry.

Furthermore, the study revealed a positive and insignificant relationship between competitor financial statement performance appraisal and net profit margin. This led to the acceptance of $\mathrm{Ho}_{3}$. This finding may be a result of the value listed financial institutions placed on the review of competitors financial statements in the industry. Most firms in the industry don't see any meaningful reason to review and analyse the financial statement of competitors, as to them it does not portray the competitor's strength. This finding is in contrast to the finding of GruetterSettele (1999) that revealed that competitors annual financial statement analyses influence a company's competitive advantage and it should be a fixed part of competitive accounting. He further concluded that there is a connection between the strategic decisions of companies and their knowledge of financial statement ratios of competitors. This finding implies that managers of listed financial institutions in Nigeria should reorient themselves on the relevance and need to analyse the financial statement of competitors to gain a competitive advantage and be profitable.

\section{Conclusion}

Through competitor accounting, firms identify who their key competitors are, develop a profile for each of them, identify their objectives and strategies, assess their strengths and weaknesses, gauge the threat they pose and anticipate their reaction to competitive moves. Firms that develop systematic and advanced competitor accounting have a significant competitive advantage in terms of profitability. Conclusively, it can be agreed upon that from all indications there is an in-depth need for competitor accounting for profitability of listed financial institutions in Nigeria as revealed by this study. Therefore, there is a significant relationship between competitor accounting and profitability of listed financial institutions in Nigeria.

\section{Recommendations}

The following recommendations were made in respect to the findings of the study.

I. Since the impact of competitor cost assessment on net profit margin of listed financial institutions in Nigeria is significant, managers and directors of listed financial institutions should fully embrace the practice of competitor accounting and give more attention to competitors cost assessment.

II. Listed financial institutions in Nigeria should set up a special unit from the accounts and marketing departments to ascertain on regular basis the competitive position of their respective firms in the industry for increased profitability.

III. Decision-makers within the financial institution should place more emphasis on the financial statement performance appraisal of its competitors for information that will lead to competitive advantage.

\section{References}

Akenbor, C. O., \& Okoye, E. I. (2011). Competitor accounting and corporate profitability of manufacturing firms in Nigeria. ESUT Journal of Management Sciences, 6(1), 1-15.

Alsoboa, S. S., \& Alalaya, M. M. (2015). Practices of competitor accounting and its influence on the competitive advantages: An empirical study in Jordan manufacturing 
companies. Global Journal of Management and Business Research: Accounting and Auditing, 15, 13-23.

Chiekezie, N. R., Egbunike, P. A., \& Odum, A. N. (2014). Adoption of competitor focused accounting methods in selected manufacturing companies in Nigeria. Asian Journal of Economic Modeling, 2(3), 128-140.

Chukwu, G. J., \& Egbunike, P. A. (2017). Chief executive officers' human capital and firm performance. ICAN Journal of Accounting and Finance (Academic Conference Special Edition), 3(1), 64-74

Chukwu \& Salifu. (2018), Purchased goodwill and financial performance of banks in Nigeria. IOSR Journal of Business and Management, 20(10), 52-58

Egbuhuzor, C. A. (2016). Value engineering and profitability of public limited companies in Nigeria. Journal of Poverty, Investment and Development, 26(1), 58-63.

Enekwe, C. I., Okwo, I. M., \& Ordu, M. M. (2013). Financial ratio analysis as a determinant of profitability in Nigerian pharmaceutical industry. International Journal of Business and Management, 8(8), 107-117.

Feng, L., Russell, J. L., \& Michael, M. (2013). A measure of competition based on 10-K filings. Journal of Accounting Research, 52(2), 399-436. https://doi.org/10.1111/j.1475679X.2012.00472.x

Gruetter-Settele, A. (1999), Behavioural effects of information from external accounting. Settle, Augsburg.

Heinen, C., \& Hoffjan, A. (2005). The strategic relevance of competitor cost assessment: An empirical study of competitor accounting. Journal of Management Accounting Research, 3(1), 17-21.

Hesford, J. W. (2008). An empirical investigation of accounting information use in competitive intelligence. Journal of Competitive Intelligence and Management, 4(3), 17-49.

Husnan, S. (2001). Financial management theory and application (short term decisions). BPFE.

Jensen, M. C., \& Meckling, W. H. (1976). Theory of the firm: managerial behavior, agency costs and ownership structure. Journal of Financial Economics, 3(4), 305-360.

Phornlaphatrachakorn, K. (2019). Competitor accounting and marketing performance: An empirical investigation of electronics and electrical appliance businesses in Thailand. University of the Thai Chamber of Commerce Journal Humanities and Social Sciences, 37(4), 35-55.

Piatkowski, M. (2012). Factors strengthening the competitive position of SME sector enterprises. An example for Poland. International strategic management conference, Cracow: Social and Behavioral Sciences, 58, 269-278.

Shapiro, A. C. (1991). Modern corporate finance. Macmillan.

Shecderbek, M. (2010). Effect of competitor costs assessment on the performance of manufacturing and services industries in selected European companies. Journal of International Business Research, 5(1), 45-59.

Sliman, S. A., \& Mohammad, M. A. (2015). Practices of competitor accounting and its influence on the competitive advantages: An empirical study in Jordanian manufacturing 
companies. Global Journal of Management and Business Research: D Accounting and Auditing. 15, 13-23.

Tan, Y. (2016). The impacts of risk and competition on bank profitability in China. Journal of International Financial Markets, Institutions and Money, 40, 85-110

Tipuric, D. (2008). Corporate governance synergy. CIRU.

Twonbull, S. (1997). Corporate governance: its scope, concerns, and theories, corporate governance. An International Review, 5(4), 180-205.

Usman, S., \& Bello, M. M. (2019). Application of competitor focused accounting (cfa) method as competitive advantages in foods and baking enterprises in Kano, Jigawa and Bauchi States of Nigeria. International Journal of Research and Innovation in Social Science (IJRISS), 3(2), 208-216.

Vladimirov, Z., Simeonova-Ganeva, R., \& Ganev, K. (2012). Interaction of leading and supporting factors for the SME competitiveness. Munich Personal RePEc Archive. https://mpra.ub.uni-muenchen.de/37251/

Ward, K., Hewson, W., \& Srikanthan, S. (1992). Accounting for the competition. Management Accounting (UK), 70, 19-20.

Yuanita, N. (2019). Competition and bank profitability. Economic Structures 8(31). https://doi.org/10.1186/s40008-019-0164-0 